\title{
Kajian Pengelolaan Personnel Files Berbasis Elektronik: Studi Kasus Kantor Regional II Badan Kepegawaian Nasional (BKN) Surabaya
}

\author{
Failina Zuhrotun Napsi \\ PT Taspen (Persero) Kantor Cabang Pamekasan
}

\begin{abstract}
This paper examines the procedures for managing electronic files based personnel. The research locus is in Regional Office II of the National Personnel Agency (BKN) Surabaya. Human resource management organizations create personnel files or personnel files that are managed in a certain way in accordance with the vision and mission. Basically, personnel files created by the State Personnel Agency are a vital type of archive. The data used consists of primary data and secondary data. Data collection methods used in this study are observation, interviews, and literature study. Observations or observations made at the Regional Office II of the National Personnel Agency (BKN) Surabaya. The interview aims to add information through the staffing administration. Literature study is used to collect data in order to strengthen the exposure that has been described by the author. Management of personnel files at Regional Office II of the Surabaya National Personnel Agency (BKN) based on the storage media is done physically and electronically. Electronically, the management of personnel files is carried out starting from scanning or scanning, storing and maintaining.
\end{abstract}

\section{INTISARI}

Makalah ini mengkaji tentang prosedur pengelolaan personnel files berbasis elektronik. Lokus penelitian berada di Kantor Regional II Badan Kepegawaian Nasional (BKN) Surabaya. Organisasi pengelola sumber daya manusia menciptakan arsip kepegawaian atau personnel files yang dikelola dengan cara tertentu sesuai dengan visi dan misi. Pada dasarnya, personnel files yang diciptakan oleh Badan Kepegawaian Negara merupakan salah satu jenis arsip vital. Data yang digunakan terdiri dari data primer dan data sekunder. Metode pengumpulan data yang digunakan dalam penelitian ini yaitu observasi, wawancara, dan studi pustaka. Observasi atau pengamatan dilakukan di Kantor Regional II Badan Kepegawaian Negara (BKN) Surabaya. Wawancara bertujuan untuk menambah informasi melalui pengelola tata naskah kepegawaian. Studi pustaka digunakan untuk mengumpulkan data demi memperkuat paparan yang telah dijelaskan penulis. Pengelolaan personnel files di Kantor Regional II Badan Kepegawaian Negara (BKN) Surabaya berdasarkan media penyimpanannya dilakukan metode konvensional fisik dan berbasis elektronik. Pengelolaan personnel files berbasis elektronik terdiri dari tahapan pemindaian atau scanning, penyimpanan, dan pemeliharaan.
Submitted: 22/11/2019

Received: 22/01/2020

*Correspondence: Failina Zuhrotun Napsi failinanapsi@ymail.com

KEYWORDS: managing, personnel, files, electronic

KATA KUNCI: pengelolaan, personnel, files, elektronik

CITE THIS ARTICLE:

Napsi, F. Zuhrotun. (2019). Kajian

Pengelolaan Personnel Files Berbasis Elektronik: Studi Kasus Kantor Regional II Badan Kepegawaian Nasional (BKN) Surabaya. Jurnal Diplomatika, 3(1), 63-73. 


\section{PENDAHULUAN}

Di abad informasi, kebutuhan masyarakat atas informasi semakin meningkat tajam. Informasi telah menjadi bagian hidup vital bagi manusia. Ragam tuntutan hidup, seperti pekerjaan maupun pendidikan menjadikan seorang individu terus berupaya untuk terus terhubung dengan informasi. Kegiatan menelusuri informasi yang disertai dengan proses berpikir individu dapat menciptakan informasi baru.

Dalam dinamika operasional organisasi, khususnya organisasi publik, kegiatan menciptakan dan memberikan informasi harus dapat dikomunikasikan. Komunikasi yang bersifat legal dibuktikan oleh suatu rekaman tertulis yaitu arsip. Arsip adalah rekaman kegiatan atau peristiwa dalam berbagai bentuk dan media sesuai dengan perkembangan teknologi informasi dan komunikasi yang dibuat dan diterima oleh lembaga negara, pemerintahan daerah, lembaga pendidikan, perusahaan, organisasi politik, organisasi kemasyarakatan, dan perseorangan dalam pelaksanaan kehidupan bermasyarakat, berbangsa, dan bernegara (Arsip Nasional RI, 2009, 2).

Arsip memiliki fungsi sebagai sumber informasi dan pusat ingatan bagi organisasi. Arsip menurut fungsinya dalam operasional organisasi diklasifikasikan menjadi dua yaitu arsip dinamis dan arsip statis. Arsip dinamis adalah arsip yang masih berada di berbagai kantor, baik kantor pemerintah, swasta, atau organisasi kemasyarakatan, karena masih dipergunakan secara langsung dalam perencanaan, pelaksanaan, dan kegiatan administrasi lainnya (Amsyah, 1991, 2). Wujud nyata arsip dinamis yang paling mudah dijumpai adalah korespondensi; baik surat masuk, surat keluar, surat perjanjian, maupun surat lainnya serta notulensi. Menurut perundangundangan, arsip dinamis adalah arsip yang digunakan secara langsung dalam kegiatan pencipta arsip dan disimpan selama jangka waktu tertentu (Arsip Nasional RI, 2009, 3). Periode simpan arsip dinamis bergantung pada dua hal, yaitu nilai guna dan Jadwal Retensi Arsip (selanjutnya disebut JRA). JRA merupakan salah satu dari empat pilar kearsipan. JRA menjadi penentu lama waktu simpan arsip, jenis arsip, dan menentukan apakah suatu arsip harus dinilai kembali, dapat dimusnahkan, atau simpan permanen. Arsip dinamis, berdasarkan frekuensi penggunaannya dalam operasional organisasi, diklasifikasikan kembali menjadi dua yaitu dinamis aktif dan dinamis in-aktif. Arsip dinamis aktif adalah arsip yang frekuensi penggunaannya tinggi dan/atau terus menerus (Arsip Nasional RI, 2009, 3). Wujud nyata arsip dinamis aktif salah satunya adalah rencana anggaran tahunan yang masih berjalan. Arsip tersebut akan terus digunakan sebagai pedoman pengeluaran dana suatu organisasi selama satu tahun penuh. Adapun arsip inaktif adalah arsip dinamis yang frekuensi penggunaannya mulai menurun (Arsip Nasional RI, 2009, 3). Arsip dinamis inaktif, meski jarang digunakan atau diakses, tetap disimpan sebab diprediksi akan dimanfaatkan untuk keperluan tertentu. Misalnya, rencana anggaran tahunan yang telah habis masanya akan tetap disimpan dalam beberapa tahun kemudian untuk bahan evaluasi organisasi secara berkala dan untuk memenuhi persyaratan audit.

Arsip dinamis aktif merupakan bagian yang sangat penting bagi operasional organisasi. Hal ini karena arsip tersebut masih terus digunakan dalam kegiatan operasional organisasi dan terkait dengan hajat hidup orang banyak. Arsip dinamis aktif juga berfungsi sebagai dasar pelaksanaan tugas dan pengambilan keputusan dalam suatu organisasi. lokasi penyimpanan arsip dinamis aktif disebut sebagai Pusat Arsip atau Central File. Sedangkan arsip dinamis in-aktif disebut dengan istilah non current records. Sebagaimana arsip dinamis aktif, arsip dinamis in-aktif juga menjadi bahan referensi dalam pembuatan kebijakan yang ada disuatu organisasi meski intensitasnya tidak setinggi arsip dinamis aktif. Pada umumnya, arsip dinamis inaktif 
yang dikelola oleh organisasi merupakan dokumen yang memiliki beberapa komponen, seperti laporan pertanggung jawaban. Arsip dinamis in-aktif disimpan di suatu Record Center.

Urgensi keberadaan suatu arsip berbeda-beda untuk setiap organisasi. Hal tersebut berdampak pada bentuk pengamanan yang dilakukan yang juga berbeda bergantung pada tata kelola organisasi pencipta arsip. Sayangnya, belum semua organisasi publik di Indonesia telah difasilitasi dengan tempat penyimpanan arsip yang terintegrasi. Fenomena tersebut disebabkan oleh tingkat kesadaran dibidang kearsipan pun berbeda-beda dan cenderung rendah. Beberapa organisasi publik memang terbukti telah memiliki tempat penyimpanan arsip, namun yang perlu diperhatikan lagi apakah pengelolaan dokumen sesuai dengan standar kearsipan serta memenuhi kualifikasi dari aspek keamanan, penataan dan penemuan kembali yang juga sesuai dengan standar, lokasi yang aman dari bencana alam maupun manusia, dan kondisi tempat penyimpanan arsip yang sesuai standar dan mendukung kelestarian fisik dan informasi arsip, dan lain sebagainya.

Lembaga publik pasti menciptakan arsip yang berkaitan dengan visi dan misi organisasi. Setiap organisasi memiliki karakter arsip yang khusus bergantung pada bidang yang dikelola. Organisasi yang bergerak pada persoalan pengelolaan sumber daya manusia pasti menciptakan arsip kepegawaian atau personnel files. Kantor Regional II Badan Kepegawaian Negara (BKN) Surabaya adalah lembaga publik non pemerintahan, bertanggungjawab di bidang manajemen kepegawaian negara. Berdasarkan survei awal yang penulis lakukan di Kantor Regional II Badan Kepegawaian Negara (BKN) Surabaya pada Kamis, 03 Agustus 2017, arsip yang terdapat pada institusi tersebut berupa arsip kepegawaian atau personnel files PNS seProvinsi Jawa Timur yang dikategorikan sebagai vital records. Arsip tersebut disimpan di pusat simpan arsip dengan penataan khusus. Personnel files dikategorikan sebagai arsip vital sebab menyangkut hajat hidup Pegawai Negeri Sipil (PNS) dan mengandung nilai administrasi, hukum, keuangan, riset, dan dokumentasi. Hilangnya personnel files dapat berdampak signifikan, salah satunya pada pengelolaan keuangan karena berkaitan dengan masalah gaji, tunjangan, asuransi, hutang, dan sebagainya.

Pengelolaan personnel files di Kantor Regional II Badan Kepegawaian Negara (BKN) Surabaya telah dibekali pedoman khusus. Pedoman tersebut adalah Peraturan Kepala Badan Kepegawaian Negara Nomor 18 Tahun 2011 tentang Pedoman Pengelolaan Tata Naskah Kepegawaian Pegawai Negeri Sipil. Pedoman tersebut menjadi panduan dalam pengelolaan personnel files, baik dengan metode konvensional maupun berbasis elektronik. Prosedur pengelolaan personnel files dengan metode konvensional meliputi pemilahan jenis arsip yang akan disimpan, pencatatan, penyimpanan, pemeliharaan, pelayanan informasi, dan sarana prasarana. Prosedur pengelolaan personnel files berbasis elektronik, pada prinsipnya tidak jauh berbeda dengan pengelolaan secara fisik. Perbedaan paling signifikan hanya pada tahapan pencatatan yang diubah menjadi tahapan pemindaian atau scanning. Namun dalam praktiknya, terdapat beberapa kesenjangan yang disebabkan oleh kurangnya pemahaman mengenai prosedur pengelolaan personnel files dan persoalan sarana prasarana yang berbeda dengan organisasi lain. Makalah ini berfokus pada pengelolaan personnel files berbasis elektronik. 
Berdasarkan latar belakang tersebut, maka penulis merumuskan masalah yaitu adalah bagaimana pengelolaan personnel files berbasis elektronik di Kantor Regional II Badan Kepegawaian Negara (BKN) Surabaya?

\section{METODE PENELITIAN}

Penelitian ini merupakan jenis penelitian kualitatif deskriptif dengan pendekatan studi kasus, yaitu mendeskripsikan prosedur pengelolaan personnel file yang berbasis elektronik. Adapun lokus penelitian difokuskan di Kantor Regional II Badan Kepegawaian Negara (BKN) Surabaya, tempat penulis melaksanakan praktik kerja lapangan. Data dikumpulkan melalui tiga metode, yaitu:

1. Observasi-partisipatif, yaitu penulis mengamati pengelolaan personnel files. Selain itu, penulis juga ikut serta terlibat dalam proses pengelolaan tersebut, kemudian menganalisis apakah sudah sesuai dengan teori dan standar dibidang kearsipan. Observasi ini lebih mengarah kepada partisipasi dan analisis sehingga penulis dapat mengetahui secara jelas dan tepat proses pengelolaan personnel files berbasis elektronik;

2. Wawancara, yaitu melakukan wawancara kepada staff di Kantor Regional II Badan Kepegawaian Negara (BKN) Surabaya;

3. Studi Pustaka, yaitu mengkaji bahan-bahan pustaka yang berkaitan dengan topik pengelolaan personnel file dan pengelolaan arsip elektronik.

\section{HASIL DAN PEMBAHASAN}

Kegiatan pemanfaatan dan pengendalian atas sumber daya yang diperlukan untuk mencapai ataupun menyelesaikan tujuan tertentu diistilahkan sebagai pengelolaan (Atmosudirjo, 1982, 10). Pengelolaan arsip dibagi menjadi dua, yaitu pengelolaan arsip dinamis dan pengelolaan arsip statis. Berdasarkan konsep daur hidup arsip, pengelolaan arsip dinamis terdiri dari create, use and maintenance, dan disposal. Tahapan penciptaan atau creation dilaksanakan sesuai dengan pedoman tata naskah di masing-masing organisasi. Setelah tahap penciptaan, arsip disimpan sesuai dengan sistem penyimpanan yang dipilih organisasi. Tahap akhir dari pengelolaan arsip dinamis adalah disposal atau penyusutan. Penyusutan dilakukan berdasarkan Jadwal Retensi Arsip (JRA) di masing-masing organisasi. Arsip dinamis yang sudah dinyatakan 'jatuh tempo', dinilai kembali untuk menentukan apakah arsip tersebut harus musnah atau dipindah.

Arsip kepegawaian memiliki nama lain yaitu personnel files. File dan record memiliki makna yang berbeda (Kadir, 2002, 8). File merupakan kumpulan data perorangan sedangkan record merupakan data satu orang. Adapun contoh file adalah Sukarti-Guru-Semarang, Ucok-Dokter-Nias, dan Pace-Insinyur-Papua. Sedangkan contoh record adalah Sukarti-Guru Surabaya. Selain itu, Minnesota's Government Data Practices Act (MGDPA) mendefinisikan data kepegawaian sebagai berikut: Personnel Data are information about an individual collected and maintained because the person has or had an employment relationship with the city (League of Minnesota Cities Information Memo, 2017, 1). Personnel Data didefinisikan sebagai informasi mengenai seseorang, yang dikumpulkan dan diolah karena seseorang tersebut berprofesi sebagai 
pekerja. Personnel Data mengacu pada informasi sedangkan personnel files dan/atau personnel records lebih kepada objek atau bentuk fisik.

Berdasarkan hasil survei awal di Kantor Regional II Badan Kepegawaian Negara (BKN) Surabaya pada Kamis, 03 Agustus 2017, salah satu arsip substantif yang dikelola oleh BKN Kantor Regional II adalah berupa arsip kepegawaian. Arsip tersebut dapat diklasifikasikan sebagai arsip vital. Adapun wujud nyata arsip tersebut berupa personnel files PNS se-Provinsi Jawa Timur yang disimpan di pusat arsip dan memiliki pola penataan tersendiri. Personnel files diklasifikasikan sebagai arsip vital sebab memiliki konten berupa data pribadi Pegawai Negeri Sipil (PNS) yang mengandung nilai administrasi, hukum, keuangan, riset, dan dokumentasi. Apabila suatu personnel file hilang, dampak yang paling berpengaruh adalah nilai fiskal atau keuangan. Hal ini karena bersangkut paut dengan masalah gaji, tunjangan, asuransi, hutang, dan sebagainya.

Pengelolaan personnel files dilakukan secara fisik dan elektronik. Personnel files yang masih berstatus dinamis aktif akan dikelola oleh Seksi Pengelolaan Arsip Kepegawaian Instansi Vertikal dan Propinsi dan Seksi Pengelolaan Arsip Kepegawaian Instansi Kabupaten dan Kota. Berdasarkan tempat penyimpanannya, Kantor Regional II Badan Kepegawaian Negara (BKN) Surabaya menganut asas kombinasi dan tergolong on-site. Semua tata naskah/personnel records disimpan secara terpusat di Lantai 3 Gedung Induk yang terhubung dengan Gedung Arsip. Cara penyimpanan ini tergolong on-site karena ruang penyimpanan menjadi satu dengan gedung induk tempat aktivitas organisasi.

Jumlah sumber daya manusia pengolah personnel files di Kantor Regional II Badan Kepegawaian Negara (BKN) Surabaya berjumlah 42 orang dengan jumlah beban kerja sebanyak 435.930 personnel records. Data tersebut diperoleh dari Rincian Jumlah Beban Kerja PNS Pusat dan Daerah Tahun 2017 di Seksi Pengelolaan Arsip Kepegawaian Instansi Vertikal dan Propinsi dan Seksi Pengelolaan Arsip Kepegawaian Instansi Kabupaten dan Kota.

Personnel files yang dikelola oleh Kantor Regional II Badan Kepegawaian Negara (BKN) Surabaya termasuk dalam arsip dinamis. Pengelolaan arsip dinamis idealnya dilakukan berdasarkan daur hidup; yaitu create, use and maintenance, dan disposal. Kanreg BKN menciptakan arsip kepegawaian berupa Nota Persetujuan Kenaikan Pangkat, Surat Keputusan Pindah Instansi, Surat Keputusan Pindah Wilayah Kerja, dan beberapa arsip lain.

Pengelolaan personnel files berbasis elektronik dimulai dari tahapan alih media. Proses alih media dari bentuk fisik kedalam bentuk elektronik disebut juga digitalisasi atau document imaging. Kegiatan digitalisasi baru dimulai pada 15 Januari 2018 menggunakan aplikasi dengan server lokal, TakTronik. Berbeda dengan Document Managing System (DMS) yang digunakan oleh BKN Pusat dan kanreg lainnya, TakTronik dibuat oleh pranata di Seksi Pemanfaatan Teknologi Informasi. Namun demikian, beberapa fitur dalam aplikasi ini masih belum siap digunakan. Selain itu, aplikasi ini masih perlu dilakukan peninjauan ulang; baik dari segi efisiensi atau 
kemudahan pengguna, efektifitas waktu pengerjaan, tampilan aplikasi, penambahan fitur, integrasi online, serta beberapa evaluasi lain yang perlu dilakukan agar dapat diperbaiki.

Proses pemindaian atau scanning ini dilakukan oleh pengelola tata naskah atau personnel files. Dokumen yang dipindai menurut Peraturan Kepala Badan Kepegawaian Negara Nomor 18 Tahun 2011 tentang Pedoman Pengelolaan Tata Naskah Kepegawaian Pegawai Negeri Sipil terdiri 10 jenis. Namun berbeda dengan implementasinya, dalam formulir pengendalian, dokumen yang di-scanning di Kantor Regional II Badan Kepegawaian Negara (BKN) Surabaya sejumlah 18 jenis.

\section{Tahapan Pengelolaan Personnel Files Berbasis Elektronik}

Tahapan pertama adalah alih media. Prosedur alih media terdiri atas 3 tahap, yaitu pra-scanning, scanning, dan pasca scanning.

1. Tahap pertama yaitu pra-scanning, meliputi pengambilan dokumen personnel files dari roll o'pact, kemudian dilakukan pemilahan dokumen apa saja yang harus discan, dan memastikan jika dokumen terbebas dari klip maupun staples.

2. Kedua, tahap scanning dilakukan dengan prosedur sebagai berikut:

a. Membuka aplikasi TakTronik yang ada di dekstop PC

b. Masukkan NIP pada kolom nama user dan kata kunci lalu klik tombol masuk. Apabila berhasil masuk pada akun, nama dan NIP akan muncul pada pojok kanan bawah aplikasi.

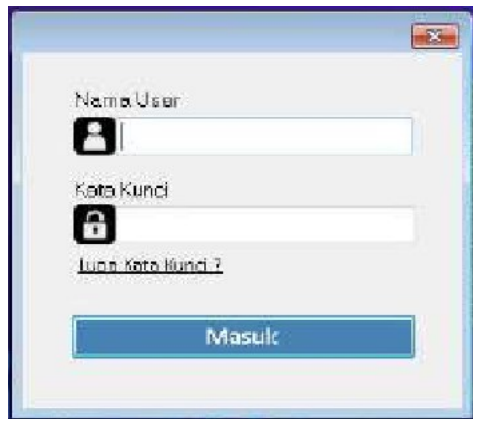

Gambar 1. Dialog Box Untuk Masuk Aplikasi

c. Penambahan dokumen, dilakukan dengan meindai dan mengunggah berkas. Namun karena fitur unggah berkas belum dapat digunakan, maka penambahan dokumen dilakukan dengan klik pada menu scan berkas seperti pada gambar berikut:

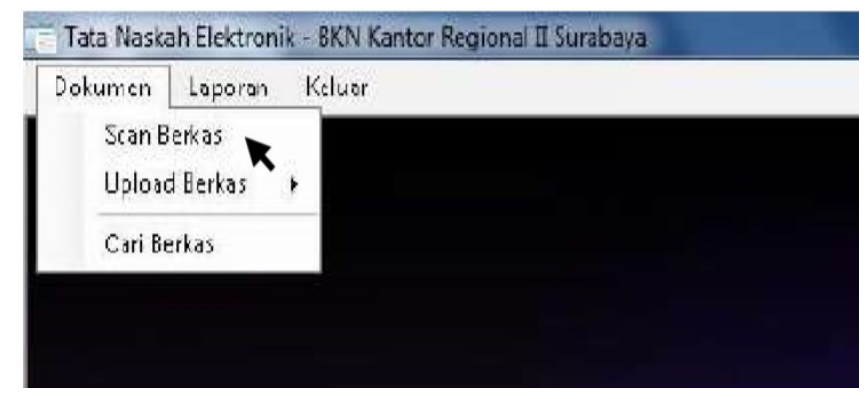

Gambar 2. Fitur Untuk Penambahan Dokumen 
d. Pilih dokumen yang akan dipindai, klik ikon segitiga kecil pada kolom instansi untuk memilih asal instansi, isi NIP sesuai dengan personnel records yang akan dipindai, lalu klik $\mathrm{OK}$.

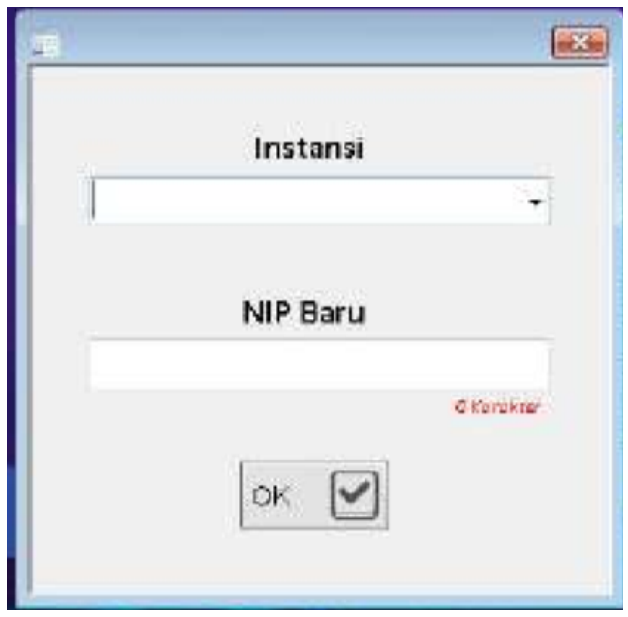

Gambar 3. Dialog Box Proses Pemindaian Dokumen

e. Posisikan dokumen yang akan dipindai pada alat pemindai sesuai dengan ukuran kertas.

f. Setelah muncul dialog box seperti gambar di bawah, klik tombol scan.

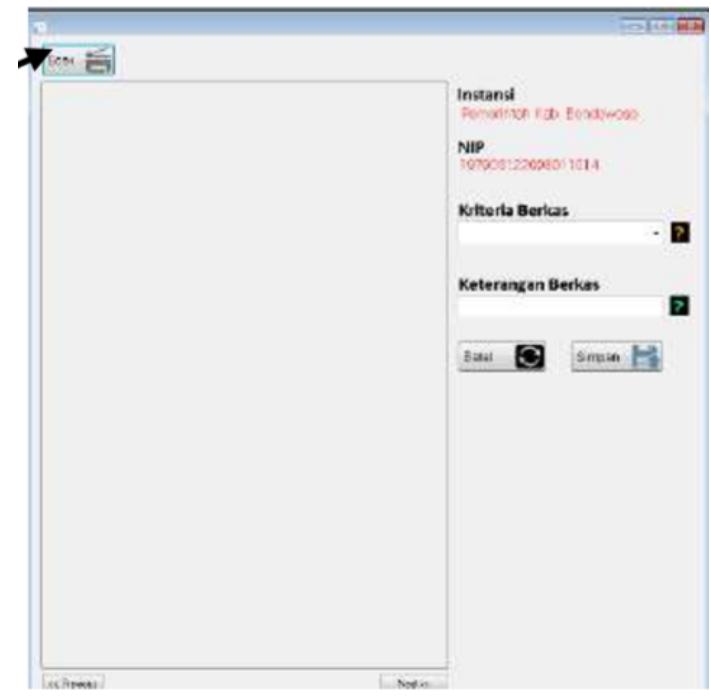

Gambar 4. Dialog Box Proses Pemindaian

g. Pilih ukuran kertas yang akan dipindai lalu klik tombol scan

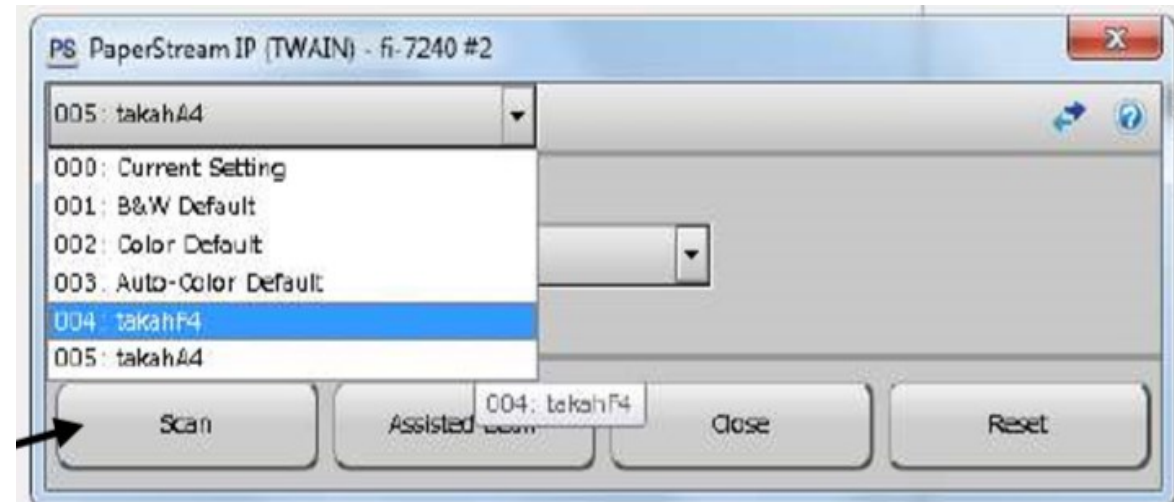

Gambar 5. Dialog Box Penyesuaian Ukuran Kertas 
h. Setelah dokumen yang dipindai muncul, pilih kriteria berkas, isi keterangan berkas. Untuk kolom "Keterangan berkas" biasanya berisi tanggal, tahun, dan bulan. Kemudian, klik simpan setelah kolom terisi

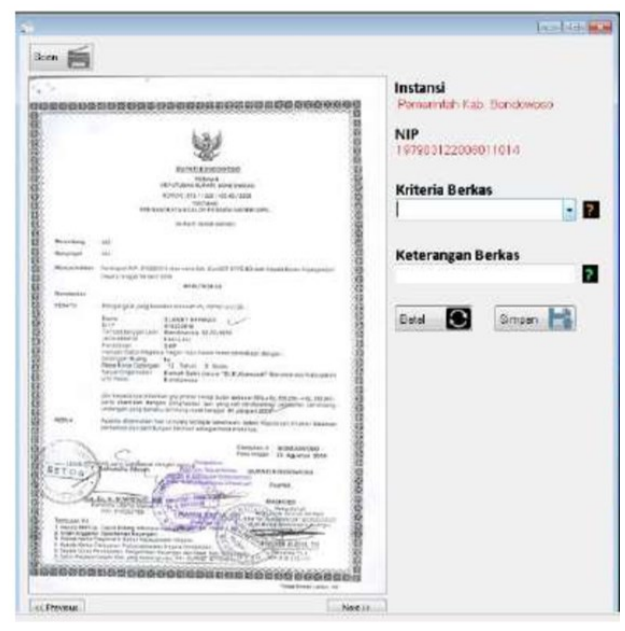

\section{Gambar 6. Dokumen Siap Dipindai}

i. Jika dokumen telah tersimpan, muncul dialog box, klik OK, kemudian klik next untuk beralih pada dokumen selanjutnya.

3. Tahap ketiga yaitu paska pemindaian. Pengelola personnel files dapat memeriksa kembali hasil kerja pada fitur 'cari berkas':

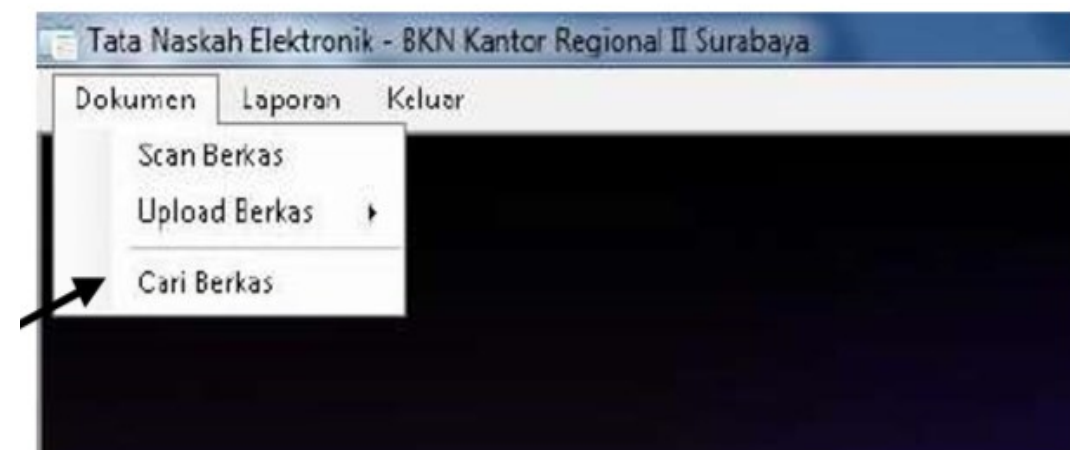

Gambar 7. Fitur Penelusuran Berkas Hasil Pemindaian

Setelah muncul dialog box pencarian, pengelola mengisi NIP sesuai personnel files yang telah disimpan.

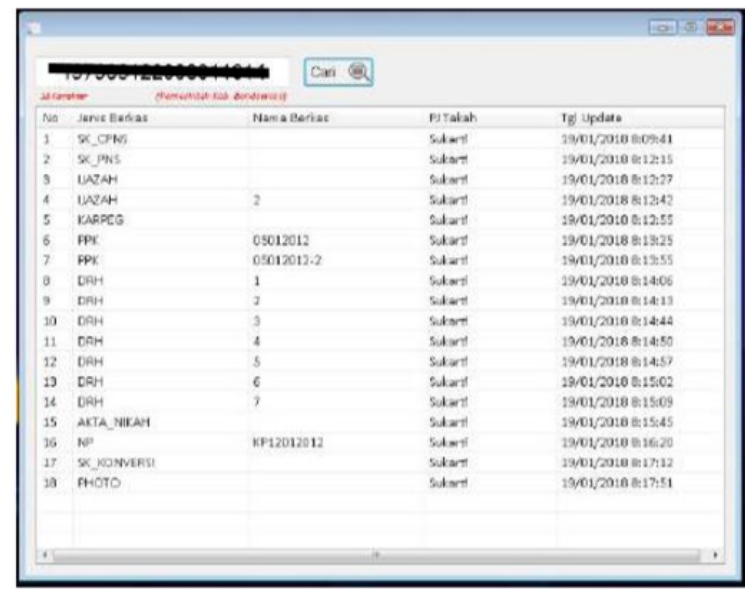

Gambar 8. Hasil Penelusuran Dokumen Hasil Pindai Yang Disimpan 
Proses alih media dapat dilakukan pada seluruh komputer di Kantor Regional II Badan Kepegawaian Negara (BKN) Surabaya terhubungan dengan jaringan internal.

Tahap berikutnya setelah dokumen dipindai adalah proses penyimpanan. Penyimpanan dilakukan otomatis saat penambahan dokumen dan tersimpan pada satu server yang dapat diakses pada direktori: \\192.168.202.13 $\backslash$ Users $\backslash$ Administrator $\backslash$ Documents $\backslash$ FILE_TAKAH $\backslash$ diikuti nama kabupaten atau kota.

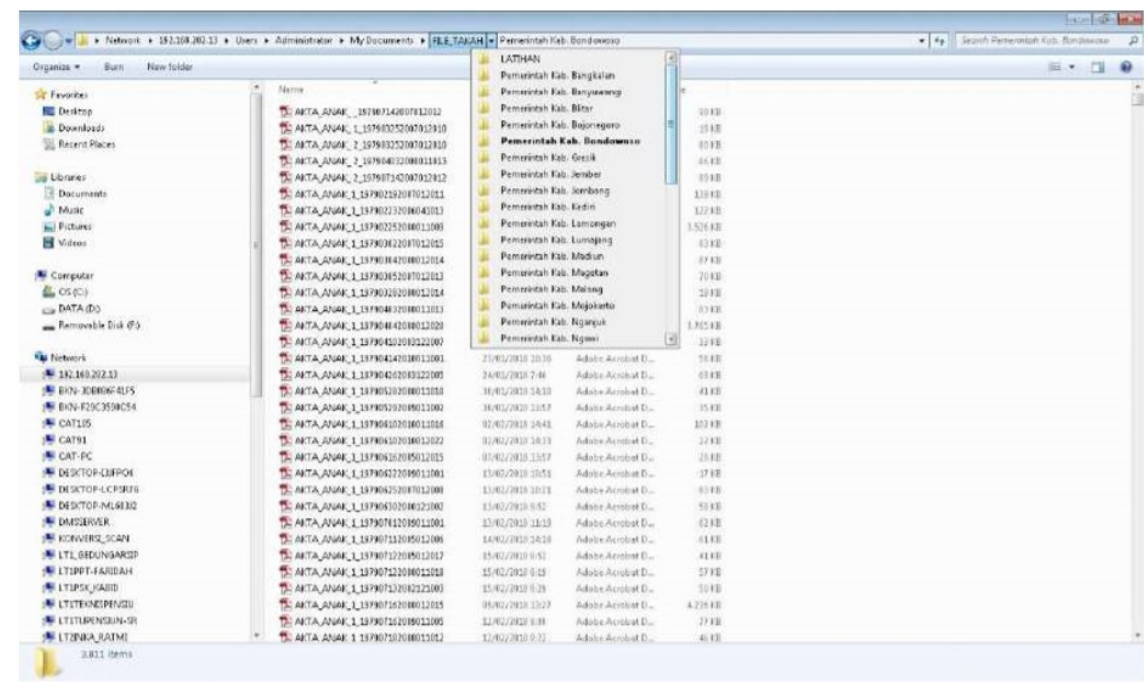

Gambar 9. Direktori Penyimpanan Dokumen Elektronik Personnel Files

Tahapan pengelolaan berikutnya terkait dengan pelestarian dokumen elektronik personnel files. Prosedur pelestarian personnel files elektronik dengan aplikasi TakTronik berdasarkan Peraturan Kepala Badan Kepegawaian Negara Nomor 18 Tahun 2011 tentang Pedoman Pengelolaan Tata Naskah Kepegawaian Pegawai Negeri Sipil terdiri dari: penambahan dokumen, hapus dokumen, dan pencarian berkas. Maka apabila pengelola personnel files akan mengubah data maka harus menghapus data yang lama dan menambah data yang baru. Selain itu, jejak aktivitas pada aplikasi tidak dapat terlacak. Maka diperlukan penambahan fitur check data, edit, dan riwayat aktivitas untuk mempermudah dan memaksimalkan pelayanan aplikasi serta keamanan informasi.

Kebijakan otomasi pengarsipan, selain mempermudah pekerjaan, tentunya tidak akan sepi dari tantangan. Pembaruan aplikasi, penambahan kualitas dan jumlah sarana alih media diharapkan dapat mempermudah pemeliharaan personnel files dalam bentuk elektronik. Selain pembaruan aplikasi, penambahan kualitas dan jumlah sarana alih media juga masih perlu dilakukan. Penambahan jumlah sarana alih media dapat diikuti dengan peningkatan spesifikasi alat agar proses alih media dapat dilakukan secara maksimal.

Hasil alih media personnel files disimpan dalam format .pdf. Format tersebut dipilih karena perkiraan usia format yang lebih tahan lama. Format .pdf juga dapat dialihkan ke format lain, seperti .jpg, .tiff, .doc, dan sebagainya. Selain itu, format .pdf dapat diakses pada perangkat elektronik apapun.

Berkaitan dengan pelayanan dokumen, pelayanan informasi dalam bentuk digital 
belum dapat dilakukan secara online sehingga pengakses harus datang langsung ke Kantor Regional II Badan Kepegawaian Negara (BKN) Surabaya.

Pengguna maupun pengelola personnel files dapat memperoleh informasi mengenai kinerja mereka dengan klik pada menu 'Laporan' lalu klik pada fitur 'kegiatan user'. Sebelum alih media resmi dilaksanakan, perlu dilakukan briefing untuk menyamakan. Persamaan persepsi tersebut dilakukan untuk pemahaman pengelola tata naskah/personnel files mengenai dokumen apa saja yang harus discan, keterangan berkas, dan penamaan kolom keterangan.

Aplikasi yang digunakan untuk proses alih media adalah TakTronik. Aplikasi dibuat oleh pranata di Seksi Pemanfaatan Teknologi Informasi. Beberapa fitur dalam aplikasi ini pada dasarnya masih belum siap digunakan. Tampilan dan fitur aplikasi pun masih tergolong rumit sehingga berpengaruh pada proses penggunaan. Adapun pengguna aplikasi adalah para pengelola personnel files yang mayoritas berusia 50 tahun keatas. Saat melakukan alih media, pengelola personnel files kesulitan dalam mencari fitur yang akan digunakan karena menu fitur berukuran kecil. Sebelum proses digitalisasi, pengelola personnel files hanya diberikan pengarahan sekali dan tanya jawab dengan pegawai dari Seksi Pemanfaatan Teknologi Informasi. Pengelola personnel files pun masih kesulitan karena alur alih media yang dinilai terlalu cepat, penggolongan kategori dan keterangan yang berbeda-beda. Permasalahan tidak konsistennya pengkategorian dan pemberian keterangan dapat mempersulit proses temu kembali.

Permasalahan tersebut pada dasarnya dapat dipecahkan dengan memperbarui versi aplikasi. Beberapa pembaruan yang harus dilakukan berupa pemilihan tampilan menu fitur yang lebih besar, design warna tampilan, penambahan fitur aktivitas akses, integrasi online, serta beberapa evaluasi lain yang kiranya perlu dilakukan agar terwujud aplikasi yang lebih baik, baik dari segi efisiensi atau kemudahan pengguna maupun efektifitas waktu pengerjaan.

Selain itu, pelatihan singkat dan jelas wajib dilakukan sebelum proses alih media dilakukan. Hal tersebut dilakukan demi keseragaman atau konsistensi input data. Persepsi atau pemahaman pengelola personnel files pun harus seragam karena apabila hal ini tidak terlaksana maka proses penemuan kembali akan sulit dilakukan.

\section{KESIMPULAN}

Pengelolaan personnel files secara elektronik oleh Kantor Regional II BKN Surabaya memanfaatkan aplikasi TakTronik. Aplikasi tersebut diciptakan pranata Seksi Pemanfaatan Teknologi Informasi menggunakan server lokal. Pengelolaan personnel files elektronik dilakukan dengan tahapan pemindaian atau scanning, penyimpanan, dan pemeliharaan. Jenis dokumen yang harus dipindai tersurat pada standar pengelolaan tata naskah kepegawaian. Namun demikian, Kantor Regional II Badan Kepegawaian Negara (BKN) Surabaya memiliki daftar jenis dokumen tersendiri sesuai dengan kebutuhan institusi. Hasil alih media personnel files disimpan pada satu komputer yang berfungsi sebagai server.

Oleh karena meningkatnya kebutuhan terhadap dokumen elektronik, maka perlu dilakukan upaya perbaikan. Pembaruan aplikasi harus dilakukan, diantaranya: 
pemilihan tampilan; baik dari segi efisiensi atau kemudahan pengguna, efektifitas waktu pengerjaan, tampilan aplikasi, penambahan fitur, dan integrasi online. Selain itu, pelatihan dan penyeragaman persepsi yang dilakukan oleh pengelola personnel files sebelum proses digitalisasi diharapkan akan mempermudah proses alih media sehingga diperoleh keseragaman data input yang serta merta akan mempermudah proses penemuan kembali.

Untuk kebutuhan terhadap personnel data PNS di seluruh Indonesia sebaiknya disediakan aplikasi yang dapat diakses secara online. Pusat personnel data secara terintegrasi dapat menjamin keseragaman data dan pembaruan informasi. Lingkup instansi yang dapat mengakses yaitu BKD, Kanreg BKN, dan BKN Pusat. Namun, tingkat keamanan aplikasi tersebut pun harus menggunakan teknologi tingkat tinggi untuk mengantisipasi terjadinya kebocoran informasi oleh pihak tidak berwenang.

\section{DAFTAR PUSTAKA}

Kadir, Abdul. (2002). Konsep \& Tuntunan Praktis Basis Data. Yogyakarta: Penerbit ANDI.

Hariyanto, "Pengolahan Personal File di Records Center Fakultas Peternakan Universitas Gadjah Mada”, Laporan Akhir D-III Kearsipan, Sekolah Vokasi, 2015.

https://kanreg2bkn.id/index.php diakses pada 16 Januari 2018 pukul 11.06 WIB.

International Records Management Trust. (1999). Managing Personnel Records. London: International Records Management Trust,.

International Records Management Trust. (2009). Managing Personnel Records in an Electronic Environment. London: International Records Management Trust

League of Minnesota Cities Information Memo: Management of Personnel Files, 2017.

Listyaning Mustikawati , "Otomasi Arsip Personalia Kepegawaian di Bagian Organisasi dan Kepegawaian Sekretariat Daerah Wonosobo", Laporan Akhir D-III Kearsipan, Sekolah Vokasi, 2016.

Ritzenthaler, Mary Lynn. (1993). Archives \& Manuscript: Preserving Archives and Manuscripts. Chicago: Society of American Archivist (SAA)

Peraturan Kepala Badan Kepegawaian Negara Nomor 18 Tahun 2011 tentang Pedoman Pengelolaan Tata Naskah Kepegawaian Pegawai Negeri Sipil.

Atmosudirjo, Prajudi. (1982). Dasar-Dasar Administrasi Niaga. Jakarta: Ghalia Indonesia

Puspita Dwi, "Pengelolaan Arsip Kepegawaian di Kantor Regional I Badan Kepegawaian Negara (BKN) Yogyakarta”, Laporan Akhir D-III Kearsipan, Sekolah Vokasi, 2014. Undang-Undang Nomor 43 Tahun 2009 tentang Kearsipan Amsyah, Zulkifli. (1991). Manajemen Kearsipan. Jakarta: PT Gramedia Pustaka Utama. 